Procedia of Engineering and Life Science Vol. 1. No. 2 June 2021

Seminar Nasional \& Call Paper Fakultas Sains dan Teknologi (SENASAINS 2nd)

Universitas Muhammadiyah Sidoarjo

\title{
The Effect of Various Comparison of the Proportions of Seaweed (Eucheuma spinosum) and Gelatin on the Characteristics of Roselle Jelly Candy (Hibiscus sabdariffa L.)
}

\section{Pengaruh Berbagai Perbandingan Proporsi Rumput Laut (Eucheuma spinosum) dan Gelatin Terhadap Karakteristik Permen Jeli Rosela (Hibiscus sabdariffa L.)}

\author{
Hikam Fuadi ${ }^{1}$, Ida Agustini Saidi ${ }^{2}$ \\ 1, 2) Program Studi Teknologi Pangan, Universitas Muhammadiyah Sidoarjo. Indonesia \\ ${ }^{1}$ xxfuadiak2@gmail.com
}

\begin{abstract}
Rosela flower (H. sabdariffa L.) is one of the plants that has many health benefits, which contain Vitamin $C$, Vitamin A, essential proteins, and 18 types of amino acids that aim to strengthen the body's immune system, treat diabetes, inhibit cancer cells and many more properties of this plant. Gelling agent commonly used to make jelly candy is gelatin, but in the application sometimes gelatin even makes the texture of jelly candy becomes very hard if the added concentration is not appropriate, besides the price of special gelatin food (food grade) is still relatively expensive compared to other hydrocolloid materials. That's why it takes another gel shaper that can improve the quality of the texture of jelly candy and suppress the use of gelatin, one of which can be used seaweed (E. spinosum). The objective of this research was to find out the effect of various proportions of seaweed (E. spinosum) and gelatin on the characteristics of roselle jelly candy (H. sabdariffa L.). The method used is non-parametric statistical tests (Friedman test) with 10 levels of treatment and performed three times the test on each treatment. The treatment that will be done is a comparison of various proportions of seaweed: gelatin, namely PI (0: 8); P2 (0: 10); P3 (25:8); P4 (25:10); P5 (30:8); P6 (30:10); P7 (35:0); P8 (35:8); P9 (40:0) and P10 (40:8). The results showed there was a very noticeable difference in all the comparative treatment of seaweed and gelatin proportions against all test parameters. The best organoleptic test results showed color organoleptic test scores of 3.00 (neutral), organoleptic textures of 3.37 (neutral-like), organoleptic flavors of 3.40 (neutral-like) and organoleptic aromas of 3.00 (neutral).
\end{abstract}

Keywords - Jelly Candy; H. Sabdariffa L.; E. Spinosum

\begin{abstract}
Abstrak. Bunga Rosela (H. sabdariffa L.) adalah salah satu tanaman yang memiliki banyak khasiat kesehatan, dimana di dalamnya terkandung Vitamin C, Vitamin A, protein essensial, dan 18 jenis asam amino yang bertujuan untuk memperkuat imun tubuh, mengobati diabetes, menghambat sel kanker dan masih banyak lagi khasiat dari tanaman ini. Bahan pembentuk gel (gelling agent) yang biasa digunakan untuk membuat permen jeli adalah gelatin, namun dalam pengaplikasiannya terkadang gelatin malah membuat tekstur dari permen jeli menjadi sangat keras jika konsentrasi yang ditambahkan tidak pas, selain itu harga dari gelatin khusus makanan ( food grade) masih relatif mahal dibandingkan dengan bahan hidrokoloid lainnya. Karena itulah dibutuhkan pembentuk gel lain yang dapat memperbaiki kualitas tekstur dari permen jeli dan menekan penggunaan gelatin, salah satunya dapat digunakan rumput laut (E. spinosum). Penelitian ini bertujuan untuk mengetahui pengaruh berbagai perbandingan proporsi rumput laut (E. spinosum) dan gelatin terhadap karakteristik permen jeli rosela (H. sabdariffa L.). Metode yang digunakan adalah uji statistika non parametrik (Uji Friedman) dengan 10 taraf perlakuan dan dilakukan tiga kali ulangan pada masing-masing perlakuan. Perlakukan yang akan dilakukan adalah perbandingan berbagai proporsi rumput laut : gelatin, yakni PI (0: 8); P2 (0: 10); P3 (25:8); P4 (25:10); P5 (30:8); P6 (30:10); P7 (35:0); P8 (35:8); P9 (40:0) dan P10 (40:8). Hasil penelitian menunjukkan terdapat perbedaan sangat nyata semua perlakuan perbandingan proporsi rumput laut dan gelatin terhadap semиa parameter uji. Hasil uji organoleptik terbaik menunjukkan nilai uji organoleptik warna 3,00 (netral), organoleptik tekstur 3,37 (netral-suka), organoleptik rasa 3,40 (netral-suka) dan organoleptik aroma 3,00 (netral).
\end{abstract}

Kata Kunci - Permen Jeli; H. Sabdariffa L.; E. Spinosum 


\section{Pendahuluan}

Permen Jeli adalah salah satu produk olahan confectionary yang banyak diminati oleh seluruh golongan masyarakat. Permen jenis ini memiliki tekstur lunak. Bahan baku utamanya adalah gula dan air yang dipanaskan hingga mengental, pada proses pembuatannya diberikan bahan hidrokoloid seperti karagenan, pektin, gum, gelatin dan lain sebagainya, guna memberikan efek kenyal pada permen. [1].

Bunga Rosela (H. sabdariffa L.) adalah salah satu tanaman yang memiliki banyak khasiat kesehatan, dimana di dalamnya terkandung Vitamin C, Vitamin A, protein essensial, dan 18 jenis asam amino yang bertujuan untuk memperkuat imun tubuh, mengobati diabetes, menghambat sel kanker dan masih banyak lagi khasiat dari tanaman ini. [2].

Bahan pembentuk gel (gelling agent) yang biasa digunakan untuk membuat permen jeli adalah gelatin. Dimana gelatin adalah biopolimer yang dapat dicampurkan dalam makanan, farmasi dan aplikasi foto. Umumnya gelatin diperoleh dari tulang dan kulit babi dan sapi. [3]. Namun dalam pengaplikasiannya terkadang gelatin malah membuat tekstur dari permen jeli menjadi sangat keras jika konsentrasi yang ditambahkan tidak pas, selain itu harga dari gelatin khusus makanan ( food grade) masih relatif mahal dibandingkan dengan bahan hidrokoloid lainnya. Karena itulah dibutuhkan pembentuk gel lain yang dapat memperbaiki kualitas tekstur dari permen jeli dan menekan penggunaan gelatin, salah satunya dapat digunakan rumput laut (E. spinosum). Di dalam rumput laut terkandung karagenan yang bisa berfungsi sebagai penstabil, pembentuk gel dan pengental [4]. Untuk itu, perlu adanya penelitian lanjutan guna menemukan konsentrasi yang presisi antara gelatin dan rumput laut, sehingga karakteristik permen jeli rosela yang dihasilkan memiliki gel yang kokoh namun mudah untuk dikunyah.

\section{Metode Penelitian}

\section{A. Tahapan penelitian}

Rumput laut 100 gram mula-mula dicuci untuk membersihkan garam yang menempel pada permukaan rumput laut. Setelah itu dilakukan pencucian hingga bersih, dilanjutkan dengan perendaman air selama 1 hari dengan prosentase air dan rumput laut adalah 10:1, hingga rumput laut mengembang dan kenyal. Proses selanjutnya adalah meniriskan rumput laut dari air rendaman, setelah itu rumput laut siap untuk di potong dengan panjang 2-3 cm untuk memudahkan penghalusan. Setelah itu rumput laut siap untuk diblender dengan prosentase rumput laut dan air adalah 2:1.

Pembuatan ekstrak bunga rosela diawali dengan pencucian bunga rosela sebanyak 15 gram menggunakan air mengalir, dilanjutkan dengan perendaman menggunakan air panas dengan suhu $\pm 90^{\circ} \mathrm{C}$ selama 1 jam. Setelah itu disaring untuk memisahkan ekstrak rosela dengan ampasnya.

Pembuatan permen jeli rosela diawali dengan penimbangan bahan, prosentase yang digunakan pada penelitian ini adalah ekstrak bunga rosela 20 gram, sukrosa 20 gram, sirup glukosa 20 gram dan asam sitrat 3 gram, kemudian ekstrak bunga rosela dimasak bersama sukrosa, glukosa dan asam sitrat pada suhu $\pm 90^{\circ} \mathrm{C}$, setelah itu dimasukkan bubur rumput laut dan gelatin sesuai perlakukan. Setelah itu diaduk secara perlahan, hingga adonan agak mengental dan mendidih, lalu diangkat dan dimasukkan kedalam cetakan, diangin-anginkan pada suhu ruang selama 1 jam, lalu dimasukkan kedalam kulkas selama 24 jam. Setelah itu permen jeli dapat dikemas kedalam plastik.

\section{B. Rancangan Percobaan}

Penelitian ini menggunakan metode uji statistika non parametrik (Uji Friedman) dengan 10 taraf perlakuan dan dilakukan tiga kali ulangan pada masing-masing perlakuan. Perlakukan yang akan dilakukan adalah perbandingan berbagai proporsi rumput laut : gelatin, yakni PI (0: 8); P2 (0: 10); P3 (25:8); P4 (25:10); P5 (30:8); P6 (30:10); P7 (35:0); P8 (35:8); P9 (40:0) dan P10 (40:8), yang bertujuan untuk mengetahui tentang pengaruh berbagai perbandingan proporsi rumput laut (E. spinosum) dan gelatin terhadap karakteristik permen jeli rosela (H. sabdariffa L.)

\section{Metode Analisis}

Permen jeli rosela yang telah jadi akan diuji organoleptik mulai dari warna, tekstur, aroma,dan rasa. [5].

\section{Hasil dan Pembahasan}

\section{A. Uji Organoleptik Warna}

Warna adalah salah satu profil visual yang dapat dilihat secara langsung dan menjadi kesan pertama terhadap kualitas suatu pangan. Warna juga menjadi faktor utama dalam menentukan menarik tidaknya suatu produk pangan [6]. Penampakan yang dianggap menarik dan baik cenderung akan dianggap memiliki rasa yang enak dan berkualitas tinggi. Oleh sebab itu penampakan warna produk merupakan atribut utama konsumen dalam memilih produk pangan melebihi atribut sensori lainnya [7]. 
Procedia of Engineering and Life Science Vol. 1. No. 2 June 2021

Seminar Nasional \& Call Paper Fakultas Sains dan Teknologi (SENASAINS $2^{\text {nd }}$ )

Universitas Muhammadiyah Sidoarjo

Hasil analisis uji Friedman menunjukkan bahwa terdapat pengaruh yang nyata $(a=0,05)$ antar perlakuan proporsi rumput laut dan gelatin terhadap kesukaan panelis akan warna permen jeli rosela. Rata-rata nilai kesukaan panelis terhadap warna permen jeli rosela dapat dilihat pada Tabel 1.

\begin{tabular}{llccc}
\hline & \multicolumn{1}{c}{ Perlakuan } & Rata-rata & \multicolumn{2}{c}{ Total ranking } \\
\hline P1 & (0 Rumput Laut : 8 Gelatin) & 4,2 & 275,5 & $\mathrm{f}$ \\
P2 & (0 Rumput Laut : 10 Gelatin) & 3,0 & 177,5 & $\mathrm{~cd}$ \\
P3 & (25 Rumput Laut : 8 Gelatin) & 2,9 & 171,5 & $\mathrm{~cd}$ \\
P4 & (25 Rumput Laut : 10 Gelatin) & 2,3 & 112,0 & $\mathrm{~b}$ \\
P5 & (30 Rumput Laut : 8 Gelatin) & 2,7 & 154,5 & $\mathrm{~cd}$ \\
P6 & (30 Rumput Laut : 10 Gelatin) & 2,6 & 135,5 & $\mathrm{bc}$ \\
P7 & (35 Rumput Laut : 0 Gelatin) & 4,2 & 278,5 & $\mathrm{f}$ \\
P8 & (35 Rumput Laut : 8 Gelatin) & 1,6 & 62,0 & $\mathrm{a}$ \\
P9 & (40 Rumput Laut : 0 Gelatin) & 3,5 & 227,0 & $\mathrm{e}$ \\
P10 & (40 Rumput Laut : 8 Gelatin) & 1,5 & 36,0 & $\mathrm{a}$ \\
\hline \multicolumn{2}{l}{ Titik Kritis } & & \multicolumn{3}{c}{35,58} \\
\hline
\end{tabular}

Tabel 1. Hasil Rata-rata Nilai Organoleptik Warna Permen Jeli Rosela

Dari Tabel 1 diatas, menunjukkan tingkat kesukaan panelis terhadap warna permen jeli rosela berkisar antara 1,5 (sangat tidak suka-tidak suka) sampai 4,2 (suka-sangat suka). Nilai kesukaan panelis terhadap warna permen jeli rosela terendah pada perlakuan proporsi rumput laut $40: 8$ gelatin (P10) yang menunjukkan nilai rata-rata kesukaan panelis terhadap warna permen jeli rosela yaitu 1,5 (sangat tidak suka-tidak suka) dan berbeda nyata dengan perlakuan yang lainnya.

\section{B. Uji Organoleptik Tekstur}

Hasil analisis uji Friedman menunjukkan bahwa terdapat pengaruh yang nyata $(a=0,05)$ antar perlakuan proporsi rumput laut dan gelatin terhadap kesukaan panelis akan tekstur permen jeli rosela. Rata-rata nilai kesukaan panelis terhadap rasa permen jeli rosela dapat dilihat pada Tabel 2.

\begin{tabular}{llccc}
\hline & \multicolumn{1}{c}{ Perlakuan } & Rata-rata & \multicolumn{2}{c}{ Total ranking } \\
\hline P1 & (0 Rumput Laut : 8 Gelatin) & 4,2 & 284,5 & $\mathrm{f}$ \\
P2 & (0 Rumput Laut : 10 Gelatin) & 3,3 & 219,5 & $\mathrm{e}$ \\
P3 & (25 Rumput Laut : 8 Gelatin) & 2,3 & 218,0 & $\mathrm{e}$ \\
P4 & (25 Rumput Laut : 10 Gelatin) & 2,8 & 168,0 & $\mathrm{~cd}$ \\
P5 & (30 Rumput Laut : 8 Gelatin) & 3,3 & 219,0 & $\mathrm{e}$ \\
P6 & (30 Rumput Laut : 10 Gelatin) & 3,0 & 186,0 & $\mathrm{de}$ \\
P7 & (35 Rumput Laut : 0 Gelatin) & 1,1 & 40,5 & $\mathrm{a}$ \\
P8 & (35 Rumput Laut : 8 Gelatin) & 2,6 & 143,5 & $\mathrm{bc}$ \\
P9 & (40 Rumput Laut : 0 Gelatin) & 1,5 & 59,0 & $\mathrm{a}$ \\
P10 & (40 Rumput Laut : 8 Gelatin) & 2,2 & 112,0 & $\mathrm{~b}$ \\
\hline \multicolumn{2}{l}{ Titik Kritis } & & 35,58 & \\
\hline
\end{tabular}

Tabel 2. Hasil Rata-rata Nilai Organoleptik Tekstur Permen Jeli Rosela

Dari Tabel 2 diatas, menunjukkan tingkat kesukaan panelis terhadap tekstur permen jeli rosela berkisar antara 1,1 (sangat tidak suka-tidak suka) sampai 4,2 (suka-sangat suka). Nilai kesukaan panelis terhadap tekstur permen jeli rosela terendah pada perlakuan proporsi rumput laut $35: 0$ gelatin (P7) yang menunjukkan nilai rata-rata kesukaan panelis terhadap tekstur permen jeli rosela yaitu 1,1 (sangat tidak suka-tidak suka) dan berbeda nyata dengan perlakuan yang lainnya.

Tekstur permen jeli rosela akan semakin keras apabila proporsi bubur rumput laut semakin sedikit dan proporsi gelatin semakin tinggi. Jika konsentrasi gelatin terlalu rendah maka gel akan menjadi lunak atau bahkan tidak tebentuk gel, namun jika terlalu tinggi konsentrasi gelatin, maka gel yang terbentuk akan kaku. [8].

\section{Uji Organoleptik Aroma}

Hasil analisis uji Friedman menunjukkan bahwa terdapat pengaruh yang nyata $(a=0,05)$ antar perlakuan proporsi rumput laut dan gelatin terhadap kesukaan panelis akan aroma permen jeli rosela. Rata-rata nilai kesukaan panelis terhadap aroma permen jeli rosela dapat dilihat pada Tabel 3 . 
Procedia of Engineering and Life Science Vol. 1. No. 2 June 2021

Seminar Nasional \& Call Paper Fakultas Sains dan Teknologi (SENASAINS 2nd)

Universitas Muhammadiyah Sidoarjo

\begin{tabular}{llccc}
\hline & \multicolumn{1}{c}{ Perlakuan } & Rata-rata & \multicolumn{2}{c}{ Total ranking } \\
\hline P1 & (0 Rumput Laut : 8 Gelatin) & 2,5 & 128,0 & $\mathrm{~b}$ \\
P2 & (0 Rumput Laut : 10 Gelatin) & 3,0 & 179,5 & $\mathrm{~cd}$ \\
P3 & (25 Rumput Laut : 8 Gelatin) & 2,2 & 86,0 & $\mathrm{a}$ \\
P4 & (25 Rumput Laut : 10 Gelatin) & 1,9 & 69,0 & $\mathrm{a}$ \\
P5 & (30 Rumput Laut : 8 Gelatin) & 3,1 & 192,5 & $\mathrm{~cd}$ \\
P6 & (30 Rumput Laut : 10 Gelatin) & 3,3 & 213,0 & $\mathrm{~d}$ \\
P7 & (35 Rumput Laut : 0 Gelatin) & 3,0 & 179,5 & $\mathrm{~cd}$ \\
P8 & (35 Rumput Laut : 8 Gelatin) & 2,9 & 170,0 & $\mathrm{c}$ \\
P9 & (40 Rumput Laut : 0 Gelatin) & 3,3 & 217,0 & $\mathrm{~d}$ \\
P10 & (40 Rumput Laut : 8 Gelatin) & 3,3 & 215,0 & $\mathrm{~d}$ \\
\hline Titik Kritis & \multicolumn{3}{c}{35,58} \\
\hline
\end{tabular}

Tabel 3. Hasil Rata-rata Nilai Organoleptik Aroma Permen Jeli Rosela

Dari Tabel 3 diatas, menunjukkan tingkat kesukaan panelis terhadap aroma permen jeli rosela berkisar antara 1,9 (sangat tidak suka-tidak suka) sampai 3,3 (netral-suka). Nilai kesukaan panelis terhadap aroma permen jeli rosela terendah pada perlakuan proporsi rumput laut $25: 10$ gelatin (P4) yang menunjukkan nilai rata-rata kesukaan panelis terhadap aroma permen jeli rosela yaitu 1,9 (sangat tidak suka-tidak suka) dan berbeda nyata dengan perlakuan yang lainnya.

Bahan pangan pada umumnya juga dikenali dari aromanya, dimana aroma akan menentukan derajat penilaian dan tingkat kualitas suatu bahan pangan, selain bentuk dan warna, aroma akan menjadi perhatian selanjutnya yang akan dipertimbangkan [9].

\section{Uji Organoleptik Rasa}

Hasil analisis uji Friedman menunjukkan bahwa terdapat pengaruh yang nyata $(a=0,05)$ antar perlakuan proporsi rumput laut dan gelatin terhadap kesukaan panelis akan rasa permen jeli rosela. Rata-rata nilai kesukaan panelis terhadap rasa permen jeli rosela dapat dilihat pada Tabel 4.

\begin{tabular}{llccc}
\hline & \multicolumn{1}{c}{ Perlakuan } & Rata-rata & \multicolumn{2}{c}{ Total ranking } \\
\hline P1 & (0 Rumput Laut : 8 Gelatin) & 2,5 & 128,0 & $\mathrm{~b}$ \\
P2 & (0 Rumput Laut : 10 Gelatin) & 3,0 & 179,5 & $\mathrm{~cd}$ \\
P3 & (25 Rumput Laut : 8 Gelatin) & 2,2 & 86,0 & $\mathrm{a}$ \\
P4 & (25 Rumput Laut : 10 Gelatin) & 1,9 & 69,0 & $\mathrm{a}$ \\
P5 & (30 Rumput Laut : 8 Gelatin) & 3,1 & 192,5 & $\mathrm{~cd}$ \\
P6 & (30 Rumput Laut : 10 Gelatin) & 3,3 & 213,0 & $\mathrm{~d}$ \\
P7 & (35 Rumput Laut : 0 Gelatin) & 3,0 & 179,5 & $\mathrm{~cd}$ \\
P8 & (35 Rumput Laut : 8 Gelatin) & 2,9 & 170,0 & $\mathrm{c}$ \\
P9 & (40 Rumput Laut : 0 Gelatin) & 3,3 & 217,0 & $\mathrm{~d}$ \\
P10 & (40 Rumput Laut : 8 Gelatin) & 3,3 & 215,0 & $\mathrm{~d}$ \\
\hline Titik Kritis & & \multicolumn{2}{c}{35,58} \\
\hline
\end{tabular}

Tabel 4. Hasil Rata-rata Nilai Organoleptik Rasa Permen Jeli Rosela

Dari Tabel 4 diatas, menunjukkan tingkat kesukaan panelis terhadap rasa permen jeli rosela berkisar antara 2,4 (tidak suka-netral) sampai 4,6 (suka-sangat suka). Nilai kesukaan panelis terhadap rasa permen jeli rosela terendah pada perlakuan proporsi rumput laut $40: 8$ gelatin (P10) yang menunjukkan nilai rata-rata kesukaan panelis terhadap rasa permen jeli rosela yaitu 2,4 (tidak suka-netral) dan berbeda nyata dengan perlakuan yang lainnya.

Rasa lebih banyak melibatkan panca indra pengecap, umumnya makanan tidak hanya terdiri dari satu kelompok rasa saja, nmaun gabungan dari beberapa rasa yang bersatu padu, sehingga menimbulkan rasa yang enak. Rasa pada umumnya dibedakan menjadi asin, asam, manis dan pahit [10].

\section{KESIMPULAN}

Perlakuan perbandingan proporsi rumput laut dan gelatin dalam pembuatan permen jeli rosela berpengaruh nyata terhadap semua nilai uji organoleptik. Hasil uji organoleptik terbaik menunjukkan nilai uji organoleptik warna 3,00 (netral), organoleptik tekstur 3,37 (netral-suka), organoleptik rasa 3,40 (netral-suka) dan organoleptik aroma 3,00 (netral). 
Procedia of Engineering and Life Science Vol. 1. No. 2 June 2021

Seminar Nasional \& Call Paper Fakultas Sains dan Teknologi (SENASAINS $2^{\text {nd }}$ )

Universitas Muhammadiyah Sidoarjo

\section{UCAPAN TERIMA KASIH}

Ucapan terimakasih ditujukan untuk Laboratorium PT. Hakiki Donarta yang telah mendukung dengan memberikan fasilitasi tempat dalam pembuatan produk dan uji organoleptik produk penelitian ini.

\section{Daftar Pustaka}

[1] SNI 3547. 2. 2008. Syarat Mutu Kembang Gula Lunak. Badan Standarisasi Nasional. Jakarta.

[2] Maryani, H., \& Kristiana, L. 2005. Khasiat dan Manfaat Rosela. Agromedia.

[3] Rismandani, M., Agustini, T. W., \& Amalia, U. 2017. Karakteristik Permen Jelly Dengan Penambahan Iota Karagrenan Dari Rumput Laut. Saintek Perikanan: Indonesian Journal of Fisheries Science anad Technology, 12(2), 103-108.

[4] Hidayat, A., Johan, V.S., \& Efendi, R. 2017. Pemanfaatan Kulit Manggis dan Rumput Laut dalam Pembuatan Permen Jelly. (Doctoral dissertation, Riau University).

[5] SNI 2346. 1. 2006. Petunjuk Pengujian Organoleptik dan atau Sensori. Badan Standarisasi Nasional

[6] Winarno, F. G. 1997. Kimia Pangan dan Gizi. Penerbit PT. Gramedia. Jakarta.

[7] Terwendah, I. P. 2017. Studi Komparasi Atribut Sensori Produk Wafer Roll dan Kesadaran Merek (Brand Awareness) Terhadap Produk wafer Roll Asteros Di Kota Kediri (Studi Kasus Di PT. Rukun Bersama Sentosa, Kediri). Doctoral Dissertation. Universitas Brawijaya.

[8] Rahmi, S. L., Tafzi, F.,\& Anggraini, S. 2012. Pengaruh Penambahan Gelatin Terhadap Pembuatan Permen Jelly dari Bunga Rosela (Hibiscus sabdariffa Linn). Jurnal Penelitian Universitas Jambi Seri Sains, 14(1): 3744.

[9] Winarno, F. G. 2004. Kimia Pangan dan Gizi. Penerbit PT. Gramedia. Jakarta

[10] Sultatry, Rubianty dan Berty Kaseger. 1985. Kimia Pangan. Kerjasama Perguruan Tinggi Negeri Indonesia Timur. 